\title{
Varieties and Accessibilities of Online Materials for Oral and Written English Skills
}

\author{
Wahyu Hidayat* \\ Postgraduate English Study Program \\ Universitas Mataram \\ Mataram, Indonesia \\ wahyu19hidayat@yahoo.com
}

\author{
Arifuddin Arifuddin \\ English Education Study Program \\ Universitas Mataram \\ Mataram, Indonesia \\ arifuddin@unram.ac.id
}

\author{
Kamaluddin Yusra \\ English Education Study Program \\ Universitas Mataram \\ Mataram, Indonesia \\ kamaludin@unram.ac.id
}

\begin{abstract}
In this digital era, the use of internet has become more popular to teachers and students. This paper aims at identifying varieties of and accessibilities to online materials for oral and written English skills. This study uses qualitative method. In collecting the data, the downloaded materials are taken from the internet sources. Then, the data were analyzed by the following procedures: collecting, classifying, identifying, and describing the nature and methods of access to the materials, assessing the suitability of the varieties and accesses to the materials from instruction and student points of views, and evaluating to what extent the online materials are relevant with oral and written skills legislated in English curriculum. The study found that, while there are varieties materials, they are not suitable with the actual classroom needs. While the materials are technologically accessible, they are actually accessible from linguistic point of view: the majority of materials are authentic and they are not made for instructional purposes. Consequently, they are less accessible to students. While more materials suitable for writing skill, materials for oral skills require more work for students to collect the relevant sources. The study also exemplified online resources for oral and written skills of English.
\end{abstract}

\section{Keywords-online materials, oral and written English skills}

\section{INTRODUCTION}

Information is a crucial and an important for every people. In the era of technological information, the use of internet becomes popular to access information on any topic of the interest and need. Information might be probably the advantage of internet that is offered. There are, thus, many available information, news, or any topics need on the internet. The Internet is a technology, which really popular in many countries across the world. In the present day, most of the people use internet to access information from the worldwide. Internet has been the most useful technology of the modern era which helps in every part of people's need moreover as the entertainment itself for them. Nowadays people live in the internet era where people can access the information in worldwide. Internet has been useful technology in the modern era which helps in working, and also in daily life as needed. For any business and company, the use of internet is really important for the promotion and development of the product. For academic necessities, internet is a source to gain the information and the component for the effectiveness of any academic system. For teachers and students, internet is really needed to use daily for their academic necessities. In this modern time, the use of internet has become the necessities for everybody to help them in their job even in their daily activities.

In every university, the emergence of internet has crucial importance to help in academic purposes. George [1] who explored the information seeking behaviour of graduate students found that students rely heavily on the Internet as well as the university libraries' online resources for information, though still using the physical library for hard copy materials such as books, journals and papers. Additionally, Kumah stated that "The Internet as a medium of communication and source of information has enabled students, researchers, business information seekers and information professionals to access information to enhance their work and communicate effectively" [2]. The use of internet now days also provides opportunities for students, teachers, researchers and everybody who need it for getting information related to academic, topics, and lots of more. For the students, the internet is widely used to gather information, find resources of learning, or gain some knowledge of various subjects. According to Bull and Ma, technology provides offers unlimited resources to language learners [3]. Thus, this statement can be proved by the real phenomenon of internet improvement used for every person around the world.

The sources of material to learn are various in Internets. The varieties of online materials can be classified into online materials for oral and written English skills. For the oral skills, it includes listening and speaking, both skills are parts of communicative language competence that have a crucial importance in communication and interaction. Developing communicative competence is important to help people in using language appropriately. Richards and Renandya [4] state that effective oral communication requires the ability to use the language appropriately in social interactions that involves not only verbal communication but also paralinguistic elements of speech such as pitch, stress, and intonation. Additionally, the others are Reading and writing. The productive writing skill is considered a cognitive challenge, because it helps assessing language competency, recalling capability and thinking ability. It demands to recall information from long-term memory [5]. Students need opportunities to develop both skills. They are extremely crucial for achieving an effectiveness of written communication. Developing students' competencies in reading and writing requires exposing students to gradually challenging reading materials and writing tasks. The goal is to make students read and write effectively.

In sum, the material that is existed should be appropriate for learners and improving a communicative competence of learning the language. Brown [6] states that the definition of a language competence as "one's underlying knowledge of system of a language, its rules of grammar, its vocabulary, and all the pieces of language and how those pieces fit 
together". Students learn and acquire language through both written and spoken ways so that they can improve their communicative competence. The key of effective learning is to meet the materials with students' needs. Tomlinson [7] describes materials as anything which can be used by teachers or learners to facilitate the learning of a language. In addition, Hutchinson and Waters [8] state that good materials contain interesting texts, enjoyable activities that engage learners' thinking capacities, give opportunities for learners to use their existing 24 knowledge and skills, and have content which both learners and teachers can cope with. Therefore, the material provided should fill what students need in order to complete the sufficient information for their academic need.

There are many advantage of using online materials for students and teachers. One of the advantages of online materials is economical, in which economic pressures make it difficult for some students to purchase many books for learning. Then, online materials come as solution, in which the students can find many free materials and books as much as they need. The next advantage of online materials is easy to carry and can be used to study everywhere. The materials are not only in the form of a textbook, but they also can be cassette, a video, a newspaper, or anything that can inform and improve the language. Since the material is in soft file, the materials can be saved in SanDisk or card memory and it makes easier for people to bring anywhere. It moreover can make easier for the students to study everywhere they feel comfortable without carry many books or any other references. Additionally, online materials also can improve students writing and computer skills. Weiner [9] found that online learning significantly improved writing and computer skills in Cyber Schools in America. This study revealed that the key to successful online learning for adolescent students lies within motivational issues and highly structured courses.

Online material have many benefit for the user especially students to find any resources. However, there are several things that should be considered in using online materials. Reading the materials in Smartphone, gadget or computer in long time period might lead to decrease the ability of vision. So, reading or studying using online material would be best in not really long period of time. Another thing that should be considered using online materials, that it may lead to students' addicted on gadget or Smartphone. Therefore, guiding and accompanying students in using online materials especially by parents is really important. The other things that should be considered in using online materials is that time consuming for searching appropriate materials. In searching for the materials, it also needs the ability to find the suitable materials as needed. Using online materials have many advantages and however have several points to be considered. Therefore, students should be smart in using it.

In 2013 curriculum, students are expected to become more active than teacher. In new curriculum, the role of teacher is as a facilitator instead of as material provider. In this new curriculum, the role of students is not only as a receiver of the material, but also as a provider the material. Students can find their own material based on the subject lessons. In order to find out the material, the book, article, internet can be as tools to support students. Therefore, students should know the material that appropriate on their level and supporting their learning.
However, not all the online material is appropriate and available for learners to gain. Some might be suitable, easy and free, and the others might be hard, cost and do not meet students need. So, based on the issues above, it motivates me to find which online material that is available and meet students need. Then it might helpful as an information and recommendation of good materials for students who want to find the materials in internet. This paper try to explore (1) What are the varieties of online material? (2) are online materials appropriate in their level and support students' need?

\section{METHOD}

The method of this study is qualitative. To take the data, it was taken and downloaded from the internet. After the data were collected, the data were analyzed by the following procedures: classifying, assessing, and concluding the result. The first step to analyze the data was by classifying them to make it easy to assess. In this research, the data were classified into oral materials and written materials.

After classifying the data, the next procedures was identifying or assessing the appropriateness, accessibilities of the data in order to know which data are free, available, and cost. Additionally, to assess the appropriateness and accessibilities of the materials, it also used interview section. 5 students that used online materials are chosen to be interviewed. It purposes to know the appropriateness and accessibilities of the material from students' point of views. It thus can be as additional information of the research.

After conducted several procedures above, then describing and concluding the result of the research, which data are free, appropriate moreover available to be used as needed and which data are not.

\section{RESULTS AND DISCUSSION}

The varieties of online material are classified into oral materials and written materials. The classification of the material is based on the 4 skills. Sadiku [10] describes the skills into "Listening and speaking are the skills that are highly interrelated and work simultaneously in real life situations. Therefore, the integration of the two aims at fostering effective oral communication. This integration will assure real-life and purposeful communication. Reading and writing are the forms a strong relationship with each other as skills. They are tools for achieving an effective written communication". In other word, these two types of online material are important to be learned as they are needed by the learner to be a communicative competent. These two are also interrelated with its component that is listening and reading as they are requirement if the learners want to be good at speaking or writing.

To access the materials, it can be found in internet. For oral materials, they can be found in YouTube which easy to access and free. Most of oral materials in YouTube are free in which it visually helps students for more understanding the information to be input into their knowledge as what they need. Then, for written materials can be found in web, blog, also in social media for instance Facebook and other media accessed. In sum, all the popular social media used above is accessible for students' materials moreover to fulfil their academic needed. 
In written materials, the result found that there are some materials which are free and cost. For free material can be found in Facebook or YouTube. Then for cost material mostly found in website. Here are some of the materials which cost found in this research, they are; Handout online, feel good English, Amazon, ego online learning and so on. Therefore, not all website information can easily help the students on finding what they need for academic purpose. The material that students learn and access should be suitable and provide students' need. Tomlinson [7] provides some principles of good materials that are concluded as; the materials should helpful, relevant, develop confidence, facilitate students' need, provide opportunities to practice, maximize learning potential, and take account in different learning style.

Based on the result of interviewing 5 students, 4 students state that they like learning through online materials, 3 students state the material is easy to understand, 3 students state the materials support their academic lesson in school and 3 students state that online materials meet their needs. Those are student's opinion about online material based on the result of interview section.

\section{CONCLUSION}

In summary, the varieties of the materials are classified into oral materials and written materials. In the accessibilities of online material, the result found that there are varieties of online material which are free, available, appropriate, and the others are not. Additionally, not all the online materials provide students 'need and appropriate for their level. Therefore, the learners should be more careful in finding the sources that can provide their needs.

\section{REFERENCES}

[1] C. George, A. Bright, T. Hurlbert, E. C. Linke, G. St. Clair, and J. Stein, "Scholarly use of information: Graduate students' information seeking behaviour," in Information Research, 2006.

[2] C. H. Kumah, "A Comparative study of use of the library and the internet as sources of information by graduate students in the university Of Ghana," Libr. Philos. Pract., 2015.

[3] S. Bull and Y. Ma, "Raising Learner Awareness of Language Learning Strategies in Situations of Limited Resources," Interact. Learn. Environ., 2001, doi: 10.1076/ilee.9.2.171.7439.

[4] J. C. Richards and W. A. Renandya, Methodology in language teaching: An anthology of current practice. Cambridge university press, 2002.

[5] R. T. Kellogg, T. Olive, and A. Piolat, "Verbal, visual, and spatial working memory in written language production," Acta Psychol. (Amst)., vol. 124, no. 3, pp. 382-397, 2007.

[6] H. D. Brown, Principles of language learning and teaching, vol. 4 Longman New York, 2000.

[7] B. Tomlinson, Materials development in language teaching. Cambridge University Press, 2011.

[8] T. Hutchinson and A. Waters, English for specific purposes. Cambridge university press, 1987.

[9] C. Weiner, "Key Ingredients to Online Learning: Adolescent Students Study in Cyberspace - The Nature of the Study," Int. J. ELearning, 2003.

[10]L. M. Sadiku, "The importance of four skills reading, speaking, writing, listening in a lesson hour," Eur. J. Lang. Lit., vol. 1, no. 1, pp. 29-31, 2015 . 